\title{
Androgen insensitivity syndrome: a review
}

Rafael Loch Batista', Elaine M. Frade Costa' ${ }^{1}$, Andresa de Santi Rodrigues ${ }^{1,2}$, Nathalia Lisboa Gomes', José Antonio Faria Jr.' , Mirian Y. Nishi' ${ }^{12}$,

Ivo Jorge Prado Arnhold', Sorahia Domenice',

Berenice Bilharinho de Mendonca ${ }^{1,2}$

\begin{abstract}
Androgenic insensitivity syndrome is the most common cause of disorders of sexual differentiation in $46, X Y$ individuals. It results from alterations in the androgen receptor gene, leading to a frame of hormonal resistance, which may present clinically under 3 phenotypes: complete (CAIS), partial (PAIS) or mild (MAIS). The androgen receptor gene has 8 exons and 3 domains, and allelic variants in this gene occur in all domains and exons, regardless of phenotype, providing a poor genotype phenotype correlation in this syndrome. Typically, laboratory diagnosis is made through elevated levels of LH and testosterone, with little or no virilization. Treatment depends on the phenotype and social sex of the individual. Open issues in the management of androgen insensitivity syndromes includes decisions on sex assignment, timing of gonadectomy, fertility, physcological outcomes and genetic counseling. Arch Endocrinol Metab. 2018;62(2):227-35
\end{abstract}

Keywords

Androgen insensitivity syndrome; androgen receptor; disorders of sex development; 46,XY DSD
${ }^{1}$ Unidade de Endocrinologia do

Desenvolvimento, Laboratório de Hormônios e Genética Molecular/ LIM42, Hospital das Clínicas, Disciplina de Endocrinologia, Faculdade de Medicina da Universidade de São Paulo (FMUSP), São Paulo, SP, Brasil ${ }^{2}$ Laboratório de Sequenciamento em Larga Escala (SELA), Faculdade de Medicina da Universidade de São Paulo (FMUSP), São Paulo, SP, Brasil

\section{Correspondence to:}

Berenice Bilharinho de Mendonca

Hospital das Clínicas,

Laboratório de Hormônios

e Genética Molecular

Av. Dr. Enéas de Carvalho Aguiar, 155,

$2^{\circ}$ andar, Bloco 6

05403-900 - São Paulo, SP, Brasil

beremen@usp.br

Received on Sep/21/2017

Accepted on Jan/18/2018

DOI: 10.20945/2359-3997000000031

\section{INTRODUCTION}

A ndrogen Insensitivity Syndrome (AIS) is an $\mathrm{X}$-linked genetic disease and it is the most common cause of disorders of sex development (DSD) in 46,XY individuals (1). The phenotype ranges from normal female external genitalia in the complete form (CAIS) to normal male external genitalia associated with infertility and/or gynecomastia in the mild form (MAIS). A large spectrum of undervirilized male external genitalia is observed in the partial form (PAIS) (2). Mutations in the androgen receptor gene $(A R)$ are found in most individuals with CAIS but in less individuals with PAIS (3).

AIS was first described by Morris, in 1953, with the clinical description of 82 female patients with testes but female phenotype and for this reason Morris named the syndrome as testicular feminization (4). Later, this syndrome was characterized for being a condition resulting from a complete or partial resistance to androgens in 46,XY individuals with normal male gonad development (5).

PAIS should be considered in all individuals with atypical genitalia at birth regardless of the degree of external genitalia virilization and MAIS is a possible diagnosis in males with persistent gynecomastia and or infertility (6).

Role of Androgens in Male Fetal Development: androgens are key elements for appropriate internal and external male sex differentiation. After normal testes development, the Leydig cells produce testosterone, which promotes Wolffian duct differentiation into epididymes, vasa deferentia and seminal vesicles (7). The conversion of testosterone to dihydrotestosterone by the $5 \alpha$-reductase type 2 enzyme promotes male external genitalia differentiation (8). In humans, the critical period for genitalia virilization occurs between 8 and 14 weeks of gestation and depends on the presence of androgens and of a functioning androgen receptor (9). Impairment of 
androgen secretion and defects in the androgen receptor will compromise the virilization process.

\section{THE HUMAN ANDROGEN RECEPTOR}

The $A R$ gene is located at chromosome $\mathrm{Xq11}-12$, is encoded by eight exons and codifies a 919 aminoacids protein (Figure 1). The $A R$ is a ligand-dependent transcription factor composed by three functional domains as the other nuclear receptors: a large $\mathrm{N}$-terminal domain (NTD) (residues 1-555), a DNAbinding domain (DBD) (556-623 residues), a hinge domain (624-665 residues) and a C-terminal ligandbinding domain (LBD) (666-919 residues) (10). The NTD is encoded by exon 1 and contains a ligandindependent transactivation function $\mathrm{l}(\mathrm{AFl})$, which contains two distinct transcription activation units: Tau-1 (aminoacids 100-370) and Tau-5 (aminoacids 360-485), that are essential for full $A R$ activity. The $\mathrm{DBD}$ is composed by two zinc fingers and connects the $A R$ to promoter and enhancer regions of $A R$ regulated genes by direct nuclear DNA binding allowing the activate functions of NTD and LBD (11). The LBD is encoded by exons $4-8$ and contains $11 \alpha$-helices associated with two anti-parallel $\beta$-sheets in a sandwichlike conformation with a central ligand binding pocket, in which the ligand can bind (12).

\section{CLINICAL PRESENTATION}

CAIS prevalence in 46,XY males is estimated from $\mathrm{l}$ in 20.400 to 1 in 99.100 (13). Except in cases of familial inheritance, CAIS is diagnosed in three scenarios: in fetal life when prenatal sex determination disclosed a $46, \mathrm{XY}$ karyotype in a fetus with female external genitalia; in childhood in a girl with inguinal hernia or at puberty in females with primary amenorrhea (14). The presence of inguinal hernia in a female child is rare and could indicate a CAIS diagnosis (13). Patients with AIS developed breasts with estradiol levels in normal male range suggesting that the lack of androgen action is the main driver of breast development in these patients, rather than an increased estrogen secretion. Menstrual cycles do not appear since normal production of antimullerian hormone $(\mathrm{AMH})$ by the testis impeded uterus, cervix and proximal vagina to development. A shortened blind-ending vagina is observed in almost all patients and the vaginal measurement varied from 2.5 to $8 \mathrm{~cm}$ in CAIS and $1.5-4 \mathrm{~cm}$ in PAIS. Pubic and axillary hair are sparse or absent $(1,14)$.

Final height in CAIS is above normal mean female height, probably due to the action of the growthcontrolling gene (GCY) located at the Y chromosome (15). Interestingly, newborns with CAIS have the same size of male newborns, suggesting that postnatal factors are involved in the final height in these individuals (16). In our cohort, the final height of CAIS individuals (165.7 $\pm 8.9 \mathrm{~cm})$ was taller than described for Brazilian females, but lower than expected for Brazilian males (15).

Differential diagnosis of CAIS includes complete gonadal dysgenesis, Mayer-Rokitanski-KusterHauser syndrome and Mullerian ducts anomalies (1). Biosynthetic enzyme deficiencies are rarely a differential diagnosis for CAIS $(8,17)$.

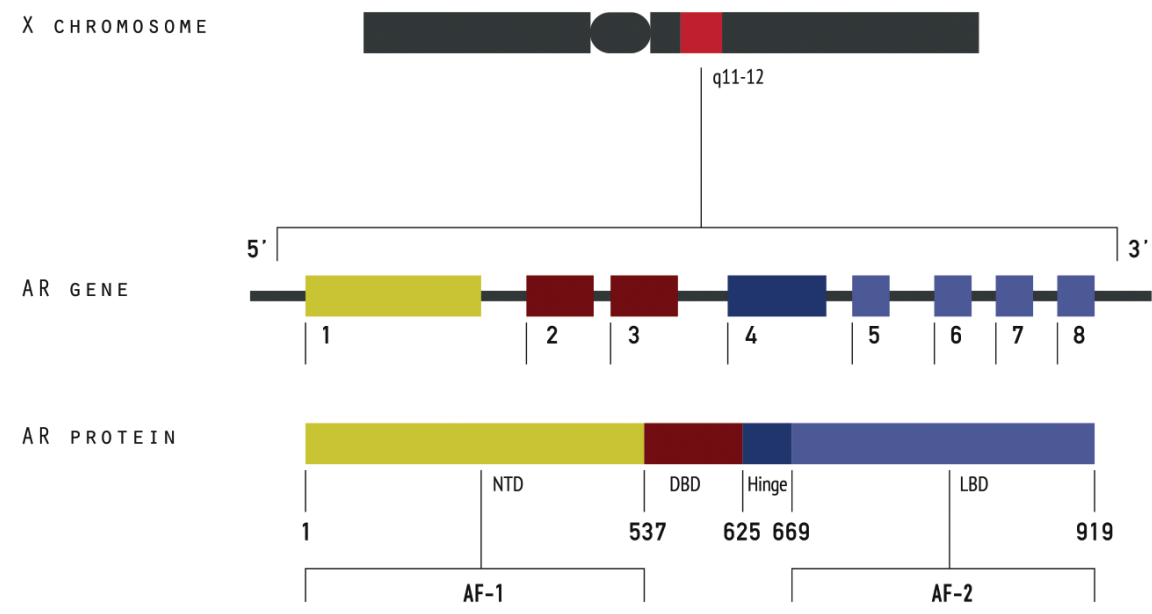

Figure 1. A schematic representation of androgen receptor gene and androgen receptor protein. 
The PAIS clinical phenotype varies according to the degree of $A R$ residual function and ranges from proximal hypospadias to micropenis (18). Hypospadias are a common finding with an estimated prevalence of 1:8000 male births and $A R$ sequencing is necessary to exclude PAIS diagnosis (19). Gynecomastia observed at puberty time in patients with atypical genitalia can be indicative of PAIS $(2,20)$. Differential diagnosis of PAIS includes all causes resulting in a undervirilized male external genitalia such as chromosomal defects (Klinefelter syndrome), genetic diseases (Smith-LemliOpitz syndrome, Denys-Drash syndrome, Frasier syndrome), partial gonadal dysgenesis, LH receptor defects, biosynthetic enzyme deficiencies (17,20-lyase deficiency, P450 oxidoreductase deficiency, $17 \beta$-hydroxysteroid dehydrogenase deficiency type 3 , $5 \alpha$-reductase 2 deficiency and hypospadias in small for gestation age boys $(8,17)$.

MAIS is associated with $A R$ mutations but without external genitalia abnormalities (6). This diagnosis could be suspected in the investigation of male infertility or in pubertal gynecomastia $(14,18)$. There are few $A R$ mutations associated exclusively with MAIS, but this condition is probably underdiagnosed $(3,6)$.

MAIS can also manifest in a patient with neurological disorder characterized by bulbar and muscular atrophy (Kennedy's disease). This condition is due to the hyperexpansion of the CAG repeats (>38), present in $A R$ exon 1 (2l). These patients present with normal male external genitalia, but testosterone resistance will develop with disease progression. For MAIS, the differential diagnosis includes other causes of male infertility.

\section{ENDOCRINE FEATURES}

In AIS the endocrine profile is consistent with androgen resistance characterized by elevated or normal basal serum testosterone levels associated with high serum LH levels (22). Elevated serum AMH and testosterone levels in a newborn suggest the diagnosis of androgen insensitivity and also exclude the diagnosis of complete gonadal dysgenesis (23). In postpuberal patients estradiol levels are normal or slightly elevated for a male individual (22). This pattern is seen at mini-puberty or after puberty. During childhood when gonadotropin axis is not activated, a hCG stimulation is necessary to evaluate testosterone secretion by Leydig cells (24). In MAIS, hormone concentrations are usually normal, but elevated serum LH and testosterone levels could be found in these patients (19).

Typically in AIS, basal testosterone and LH levels are elevated demonstrating the impairment of androgen negative feedback on the anterior pituitary (22). In contrast, FSH levels are usually normal in AIS. This is explained by the fact that FSH is mainly regulated by gonadal inhibin (25). Although there are differences in the $A R$ residual function among the mutated receptors between CAIS and PAIS phenotypes, no difference are observed in hormonal levels $(20,22)$. Serum LH, FSH estradiol, DHT were not different in subjects with CAIS and PAIS (Table 1).

\section{MOLECULAR DEFECTS IN THE ANDROGEN RECEPTOR GENE}

The AIS diagnosis is confirmed by the presence of allelic variants in the $A R$ gene $(1,26)$. About $30 \%$ of $A R$ mutations in AIS are de novo and sequencing of the entire $A R$ gene is recommended for all 46,XY DSD newborns, regardless of a familial history of DSD or AIS (26). In the absence of allelic variants in $A R$ a multiplex ligation-dependent probe amplification (MLPA) can be helpful in order to detect deletions, insertions and duplications in the $A R$ gene (26). There are more than $1000 A R$ mutations described in a website database

Table 1. Basal hormone levels in patients with AIS

\begin{tabular}{|c|c|c|c|c|c|}
\hline Phenotype & $\begin{array}{l}\text { LH } \\
(\mathrm{U} / \mathrm{L})\end{array}$ & $\begin{array}{l}\text { FSH } \\
\text { (U/L) }\end{array}$ & $\begin{array}{c}\text { Testosterone } \\
\text { ng/dL }\end{array}$ & $\begin{array}{l}\text { Estradiol } \\
\mathrm{pg} / \mathrm{mL}\end{array}$ & Reference \\
\hline CAIS & $14-43^{*}$ & $3.5-16^{*}$ & $186-1033^{*}$ & $10-40^{*}$ & (22) \\
\hline $\mathrm{n}=11$ & $26^{\star \star}$ & $7.4^{\star \star}$ & $342^{\star \star}$ & $27^{\star \star}$ & \\
\hline PAIS & $9-32^{\star}$ & $-34^{*}$ & $157-1592^{*}$ & $20-109^{*}$ & (22) \\
\hline$n=14$ & $26^{\star \star}$ & $5.0^{\star *}$ & 1032 & 49 & \\
\hline CAIS & $5.5-51$ & $0.4-16^{\star *}$ & $173-1497^{\star}$ & $4.8-70^{*}$ & (60) \\
\hline$n=42$ & 18.5 & $3.5^{\star}$ & $576^{\star \star}$ & $30.7^{\star \star}$ & \\
\hline
\end{tabular}

* Range; ** Median. 
associated with AIS and prostate cancer (http://www. mcgill.ca/androgendb) and around 600 of them were described in AIS (3). Mutations are found along the $A R$ gene, being more frequent in exon 1 (the largest $A R$ exon, which encodes the NTD). Defects in the NTD domain are more frequent in CAIS's patients and variants in exons 5 and 6 (that encode LBD) are more frequent in PAIS's patients (3). Almost all $A R$ mutations in MAIS were found in the NTD, but there is a low number of $A R$ mutations related to this phenotype.

The most common $A R$ allelic variants in all AIS phenotypes are non-synonymous point mutations. Insertions and deletions causing a frameshift leading to a premature stop codon downstream are more frequently reported in CAIS's patients. Allelic variants affecting mRNA splicing are reported in CAIS and PAIS phenotypes. Rarely, synonymous allelic variants affecting splicing sites has been described in PAIS (27) and in CAIS individuals (28).

Large structural mutations (exon 1 deletion, exon 2 duplication, exon 3 deletion, exon 4-8 (LBD domain) deletion and deletion of entire $A R$ gene) have been described but are very rare in AIS (3). Interesting, a deletion of an entire exon (exon 4) was previously described in a phenotypic male with azoospermia (29).

Postzygotic $A R$ allelic variants resulting in somatic mosaicism are rarely described in AIS (30). In this situation the variant appears in heterozygote instead of hemizygote state. $A R$ allelic variants in heterozygosis was also identified in some individuals with $47, \mathrm{XXY}$ karyotype causing AIS (31).

There is not a perfect correlation between genotype and phenotype in AIS. In the $A R$ mutation database, there are some $A R$ allelic variants that can cause different phenotypes (Table 2). The explanation for this is not completely understood. It is hypothesized that $A R$ co-regulators (activators and repressors) are implicated with this phenomenon. Other possibilities are variations in the level of $5 \alpha$-reductase type 2 activity resulting in different DHT availability, and the presence of germ-line $A R$ allelic variants at a post zygote stage conferring somatic mosaicism (31).

\section{CLINICAL MANAGEMENT OF AIS}

AIS patients have complex issues including functional, sexual and psychosocial aspects. Sex assignment, external genitalia adequacy for social sex, hormonal replacement, psychosexual outcome, ideal time for gonadectomy, infertility and genetic counseling are issues that need attention in AIS care. All of them demand flexible, sensible and individualized procedures to achieve good results.

\section{CLINICAL MANAGEMENT OF CAIS}

After diagnosis, the first aspect to be considered is the time for bilateral gonadectomy. In a girl, maintenance of the gonads will allow spontaneous breast development, though breast development is similar with estrogen replacement in gonadectomized females. So far, gonadectomy is performed at early age, in order to avoid the risk of malignancies and the psychosocial difficulties in submitting an adolescent female to gonadectomy (24). When gonadectomy is performed before puberty, estrogen replacement is necessary to induce puberty. In general, hormonal replacement is started at the age of 11-12 years with oral or transdermal estrogen. Both ways are adequate and the patient and family can choose the route in which the compliance will be better (18). Due to the absence of uterus, progesterone replacement is not necessary.

Genitoplasty is not necessary in CAIS and vaginal dilation promotes an adequate vaginal length vaginal dilation should occur after puberty or when the patient refers to desire to initiate sexual activity (32). Most of the individuals (80\%) who were submitted to vaginal dilation referred satisfactory and some of them reported dyspareunia (33). There are many vaginoplasty techniques (34), but non-surgical dilation is effective, safe, non expensive and normalizes vaginal length and

Table 2. AR allelic variants identified in more than one AIS phenotype (3)

\begin{tabular}{|c|c|}
\hline Allelic variants & Phenotype \\
\hline $\begin{array}{l}\text { p.Leu174, p.Arg616Pro, p.Asn693del, p.Asn706Ser,p.Gly744Val, p.Met746Phe, p.Met750Val, p.Trp752*, p.Ala766Thr, p.Pro767Ser, } \\
\text { p.Arg775His, p.Arg841His, p.lle843Thr, p.Val867Met, p.Val890Met, p.Ser704Gly }\end{array}$ & CAIS, PAIS \\
\hline p.Pro392Ser, p.Leu548Phe, p.Arg616His, p.Asp696Asn, p.Met781lle, p.Arg856His, p.Ala646Asp & CAIS, PAIS, MAIS \\
\hline $\begin{array}{l}\text { p.Tyr572His, p.Arg608Gly, p.Asn757Ser, p.Arg789Ser, p.Gln799Glu, p.Thr801lle, p.Ser815Asn, p.Leu822Val, p.Ala871Gly, p.Gly216Arg, } \\
\text { p.Arg608Gly }\end{array}$ & PAIS, MAIS \\
\hline
\end{tabular}


sex intercourse (32). Because of that, surgical creation of a vagina should be avoid regardless of the surgical technique (32).

\section{CLINICAL MANAGEMENT OF PAIS}

PAIS diagnosis is usually suspected in a newborn with atypical genitalia and palpable gonads. Most of the patients are raised as male. The degree of external genitalia virilization is related to the residual AR function and can be predictive of androgen response at puberty. In male patients, correction of cryptorchidism and hypospadias are recommended as soon as possible, preferably before two years of age (35).

PAIS males frequently develop gynecomastia at puberty and surgical correction is generally necessary (22). High testosterone or DHT trials (intramuscular or topic testosterone esters or topic DHT) can be use to increase penile length and to improve other virilization signs $(18,30)$. The results are unpredictable but are usually limited. Maximum virilization effect is observed after 6 months of high androgen usage treatment, subsequently, androgen therapy can be withdrawn in the patients with normal testes and preserved testosterone secretion.

For individuals raised as females, bilateral gonadectomy is recommended in childhood to avoid virilization and to eliminate the risk of testicular tumors (36). Genitoplasty is usually necessary in PAIS females and estrogen replacement is mandatory at pubertal time, with similar recommendation as describe for CAIS patients (15).

For MAIS, there is little information about clinical outcomes. Gynecomastia and infertility are the usual clinical presentation of this phenotype (6) and mastectomy is recommended for gynecomastia correction. This phenotype is observed in individuals with Kennedy's disease, which is more commonly known as spinal and bulbar muscular atrophy (SBMA). This syndrome is caused by an excessive number of CAG

Table 3. Types of androgen receptor allelic variants related to AIS reported in the androgen receptor mutations database

\begin{tabular}{lccc}
\hline Type of defect & CAIS & PAIS & MAIS \\
\hline Non-synonymous & 155 & 125 & 41 \\
Stop codon & 57 & 2 & 0 \\
Indel & 41 & 4 & 2 \\
Duplication & 6 & 0 & 0 \\
Total & 259 & 131 & 43 \\
\hline
\end{tabular}

repeats in the $A R$ exon $\mathrm{l}$ and a number of patients also have testicular atrophy, gynecomastia, oligospermia and erectile dysfunction (37).

\section{HORMONAL REPLACEMENT IN AIS}

Hormonal replacement is mandatory for all gonadectomized individuals. In females, the purpose is the development of secondary sexual characteristics and an adequate and bone mass (2). Estrogen can be introduced in low doses (one quarter of the adult dose), at $9-11$ years of age, with titration of this dosage every 6 months (20). The time for complete feminization is expected to be about 2 years. Oral or transdermic estrogen are alternative ways for estrogen replacement. The initial dose is $0.25 \mathrm{mg} /$ day of $17 \beta$-estradiol increasing the dose each 6 months considering the progression of breast development. After complete breast development, a regular dose can be introduced (1-2 mg/day of $17 \beta$-estradiol continuously) (9).

In male individuals, the testes are able to produce testosterone. In male AIS, at pubertal age, high testosterone doses (200-500 mg twice a week) can be used, in order to increase the penile size and to promote virilization (1). Maximum penile length is obtained after six months of treatment with high testosterone doses. After this period, the dose of testosterone when necessary should return to the maintenance dose. The use of DHT in male PAIS has been tested $(0.3 \mathrm{mg} / \mathrm{kg}$ of androstanolone gel $2.5 \%$ for 4 months) and mixed results were obtained following DHT therapy (38).

\section{GONADAL TUMOR RISK IN AIS}

Disorders of sex development are recognized as a risk factor for type II germ cell tumors (GCTs). These tumors are classified as seminomatous and non-seminomatous types (39). The seminomatous tumors referred to seminoma (testis) and to dysgerminoma (ovary and dysgenetic gonads). In the non-seminomatous group, many differentiated variants can be identified according to the cellular origin, being the teratomas from somatic differentiation, yolk sac tumor and choriocarcinoma from extra-embryonic differentiation, and embryonal carcinoma from stem cells (27). These tumors derivate from a non-invasive precursor named carcinoma in situ - CIS - or Intrabular germ cell neoplasia unclassified - IGCNU). In 2016, the World Health Organization suggested to change the nomenclature of 
this initial germinative neoplastic lesion from CIS or IGCNU to germ cell neoplasia in situ (GCNIS) (40). GCNIS are always non-invasive, but $50 \%$ of GCNIS progress to invasive GCTs within 5 years. The risk of GCTs development is related to the presence of a $\mathrm{Y}$ chromosome, but is not the same for the different etiologies of 46,XY DSD. So far, some factors, as chronological age and gonadal location can influence GCTs development (41).

In CAIS, the risk of GCTs is considered low and related to age (36). The estimated risk of gonadal tumors in CAIS gonads was about $0.8 \%-22 \%$ (42). However, most old series included patients without confirmed AR mutation or without description of age at gonadectomy. The reports of malignant GCTs before puberty in CAIS are very rare (43). There is only one documented report of an invasive yolk-sac tumor in a CAIS individual before puberty. This occurred in a 17-months-old CAIS girl with abdominal gonads (44). After puberty, the risk is low, but not negligible. In a study, including 133 patients with CAIS, the gonads' histological and immunohistochemical findings showed a prevalence of $1.5 \%(2 / 133)$ for malignancies (45). The low incidence of GCTs in CAIS individuals can be explain by the rapid decline of germ cells after the first year of life (46).

PAIS individuals may maintain their germ cells because of the presence of residual androgen receptor responsiveness, differently of CAIS (46). Therefore, the incidence of GCTs in PAIS (15\%) is higher than in CAIS (42). In cases of PAIS with untreated undescended testes the GCTs risk may be as high as $50 \%(47)$. Therefore, laparoscopic bilateral gonadectomy is indicated in all PAIS females and orquidopexy in scrotum in the male patients (48).

In patients who maintained the gonads, a careful monitoring including ultrasonography (US) or MRI has been suggested (43). Due to easy access and low cost, US remain the first choice for monitoring retained gonads. MRI has demonstrated adequate sensitivity to detect benign gonadal lesions, such as cysts or Sertoli cell adenomas, but failed to detect GCNIS (49). Annual US follow-up of labioscrotal and/or inguinal gonads is recommended. For abdominal gonads monitoring MRI is more helpful (50).

\section{FERTILITY IN AIS}

A normal androgen receptor is necessary for normal male reproduction, because testosterone and FSH, are essential factors for male spermatogenesis. Therefore, mutations in the androgen receptor gene have been searched in order to identify possible causes for male infertility. As previously described, infertility may be the only clinical manifestation of undervirilization in MAIS phenotype $(6,51)$.

The strategy to obtain fertility in AIS individuals has not been defined yet (52). In CAIS, there is absence of uterus and testes histology reveals incomplete spermatogenesis, increased fibrosis, Leydig cell hyperplasia and low frequency of spermatogonia conferring a very low potential to fertility. In addition, the viability of male germ cells in CAIS is restricted to the first two years of life and for fertility in adult life germ cells should be preserved before this age (46). In PAIS individuals, some residual androgen receptor function is preserved, but not usually enough to promote fertility (46). Indeed, infertility is the rule in AIS (22).

Probably, fertility is the most sensitive outcome which depends of an intact androgen receptor. For it, MAIS individuals can present only infertility $(6,51)$. However, the p.G824K and p.R840C $A R$ variant allelics, were found in male individuals with preserved fertility $(51,53)$.

A successful fertility was recently described in a PAIS individual harboring the p.V686A $A R$ variant, after prolonged high-dose testosterone therapy (250 $\mathrm{mg}$ of testosterone enanthate weekly by four years) causing improvement in sperm count. The gonadotropin concentrations remained unaffected and intracytoplasmic sperm injection with a single sperm directly into an egg resulted in proved fertility (54).

In general, infertility in AIS is the rule. The evidence of sperm count improvement after high doses of testosterone (as described above) can be an indicative of fertility success, but should be tested in further studies as well as the use of aromatase inhibitors and clomiphene citrate to obtain fertility in these patients

\section{PSYCHOLOGICAL OUTCOMES}

Psychological support is essential for AIS individuals and their parents, in general (55). Dialogue about fertility, sexuality and karyotype are delicated issues to be approached with AIS individuals.

The gender identity, gender role and sexual orientation show a female pattern in CAIS individuals. In PAIS patients, in general, gender identity aligned with both sex of rearing male or female (56). 
Gender change is very rarely described in CAIS and there are just four cases of gender change in individuals with CAIS (57). Therefore, gender dysphoria in CAIS is considered truly transgenderism. However, sexual functioning and sexual quality of life demonstrated lesspositive outcome in CAIS patients in comparison with normal woman (58).

Although there is no inconsistency in gender identity, male PAIS individuals show disappointment with undervirilization signs. The absence or paucity of facial and body hair, the high-pitched voice compromised their self-perception of manhood (59). In female individuals, low scores in feminility scales have been reported (58). An impairment of sexual functioning is reported in male and female PAIS individuals (58).

\section{CONCLUSION}

AIS is the most common molecular diagnosis in newborns with 46,XY DSD and results of an $A R$ defect. It has an X-linked inheritance and affects 50\% of the male offspring. In CAIS, the diagnosis can be done intrauterus, at birth, childhood or after puberty. In PAIS, the diagnosis is usually at birth due to the atypical external genitalia. In MAIS, the diagnosis should be considered in cases of pubertal gynecomastia and male infertility. $A R$ defects are found along $A R$ gene in all AIS phenotypes. Non-synonymous point mutations are the commonest $A R$ defects reported in AIS. Molecular diagnosis is achieved in almost all patients with CAIS and in a lower frequency in PAIS individuals. AIS is characterized by elevated serum $\mathrm{LH}$ and testosterone. In CAIS, there is a low risk of GCTs before puberty and postponing surgery to after puberty may allow the development of spontaneous puberty. In PAIS there is a risk of GCTs in $15 \%$ of the patients, and bilateral gonadectomy is recommended at childhood in all individuals raised in the female social sex. For males with PAIS, the testis should be placed in the scrotum and regularly monitored. Fertility was described in one PAIS individuals, and therapeutic strategy for successful fertility could be experienced in PAIS and MAIS individuals. In AIS, gender identity usually follows the sex of rearing, but quality of sexual life, sexual functioning and quality of life can be slightly compromised and are important issues for keeping patients in psychological care.

Funding: this work was supported by: Fundação de Amparo à Pesquisa do Estado de São Paulo Grant 2013/02162-8, Núcleo de Estudos e Terapia Celular e Molecular (NETCEM) and Conselho Nacional de Desenvolvimento Científico e Tecnológico Grant 303002/2016-6 (to B.B.M.); Fundação de Amparo à Pesquisa do Estado de São Paulo 2014/50137-5 (to SELA).

Disclosure: no potential conflict of interest relevant to this article was reported.

\section{REFERENCES}

1. Melo KFS, Mendonça BB, Billerbeck AEC, Costa EMF, Latronico AC, Arnhold IJP. [Androgen insensitivity syndrome: clinical, hormonal and molecular analysis of 33 cases]. Arq Bras Endocrinol Metab. 2005;49(1):87-97.

2. Mendonca BB, Costa EM, Belgorosky A, Rivarola MA, Domenice S. $46, X Y$ DSD due to impaired androgen production. Best Pract Res Clin Endocrinol Metab. 2010;24(2):243-62.

3. Gottlieb B, Beitel LK, Nadarajah A, Paliouras M, Trifiro M. The androgen receptor gene mutations database: 2012 update. Hum Mutat. 2012;33(5):887-94.

4. Morris JM. The syndrome of testicular feminization in male pseudohermaphrodites. Am J Obstet Gynecol. 1953;65(6):1192211.

5. McPhaul MJ, Marcelli M, Zoppi S, Griffin JE, Wilson JD. Genetic basis of endocrine disease. 4 . The spectrum of mutations in the androgen receptor gene that causes androgen resistance. J Clin Endocrinol Metab. 1993;76(1):17-23.

6. Carmina E. Mild androgen phenotypes. Best Pract Res Clin Endocrinol Metab. 2006;20(2):207-20.

7. Imperato-McGinley J, Zhu YS. Androgens and male physiology the syndrome of 5alpha-reductase-2 deficiency. Mol Cell Endocrinol. 2002;198(1-2):51-9.

8. Mendonca BB, Batista RL, Domenice S, Costa EM, Arnhold IJ, Russell DW, et al. Steroid 5 $\alpha$-reductase 2 deficiency. J Steroid Biochem Mol Biol. 2016;163:206-11.

9. Mendonca BB, Domenice S, Arnhold IJ, Costa EM. 46,XY disorders of sex development (DSD). Clin Endocrinol (Oxf) 2009;70:173-87.

10. Tan MH, Li J, Xu HE, Melcher K, Yong EL. Androgen receptor: structure, role in prostate cancer and drug discovery. Acta Pharmacol Sin. 2015;36(1):3-23.

11. Clinckemalie L, Vanderschueren D, Boonen S, Claessens F. The hinge region in androgen receptor control. Mol Cell Endocrinol. 2012;358(1):1-8.

12. Nadal M, Prekovic S, Gallastegui N, Helsen C, Abella M, Zielinska $\mathrm{K}$, et al. Structure of the homodimeric androgen receptor ligandbinding domain. Nat Commun. 2017;8:14388.

13. Oakes MB, Eyvazzadeh AD, Quint E, Smith YR. Complete androgen insensitivity syndrome - a review. J Pediatr Adolesc Gynecol. 2008;21(6):305-10.

14. Hughes IA, Werner R, Bunch T, Hiort O. Androgen insensitivity syndrome. Semin Reprod Med. 2012;30(5):432-42.

15. Danilovic DL, Correa PH, Costa EM, Melo KF, Mendonca BB, Arnhold IJ. Height and bone mineral density in androgen insensitivity syndrome with mutations in the androgen receptor gene. Osteoporos Int. 2007;18(3):369-74.

16. Miles HL, Gidlöf S, Nordenström A, Ong KK, Hughes IA. The role of androgens in fetal growth: observational study in two genetic models of disordered androgen signalling. Arch Dis Child Fetal Neonatal Ed. 2010;95(6):F435-8.

17. Mendonca BB, Gomes NL, Costa EM, Inacio M, Martin RM, Nishi MY, et al. 46,XY disorder of sex development (DSD) due to $17 \beta$-hydroxysteroid dehydrogenase type 3 deficiency. J Steroid Biochem Mol Biol. 2017;165(Pt A):79-85. 
18. Mongan NP, Tadokoro-Cuccaro R, Bunch T, Hughes IA. Androgen insensitivity syndrome. Best Pract Res Clin Endocrinol Metab. 2015;29(4):569-80.

19. Qiao L,Tasian GE, Zhang H, Cunha GR, Baskin L. ZEB1 is estrogen responsive in vitro in human foreskin cells and is over expressed in penile skin in patients with severe hypospadias. J Urol. 2011;185(5):1888-93.

20. Arnhold IJ, Melo K, Costa EM, Danilovic D, Inacio M, Domenice S, et al. $46, X Y$ disorders of sex development $(46, X Y$ DSD) due to androgen receptor defects: androgen insensitivity syndrome. Adv Exp Med Biol. 2011;707:59-61.

21. Madeira JLO, Souza ABC, Cunha FS, Batista RL, Gomes NL, Rodrigues AS, et al. A severe phenotype of Kennedy disease associated with a very large CAG repeat expansion. Muscle Nerve 2018;57(1):E95-7.

22. Melo $K F$, Mendonca $B B$, Billerbeck $A E$, Costa $E M$, Inácio $M$, Silva $F A$, et al. Clinical, hormonal, behavioral, and genetic characteristics of androgen insensitivity syndrome in a Brazilian cohort: five novel mutations in the androgen receptor gene. J Clin Endocrinol Metab. 2003;88(7):3241-50.

23. Edelsztein NY, Grinspon RP, Schteingart HF, Rey RA. Anti-Müllerian hormone as a marker of steroid and gonadotropin action in the testis of children and adolescents with disorders of the gonadal axis. Int J Pediatr Endocrinol. 2016;2016:20.

24. Ahmed SF, Cheng A, Hughes IA. Assessment of the gonadotrophingonadal axis in androgen insensitivity syndrome. Arch Dis Child. 1999;80(4):324-9.

25. Lahlou N, Bouvattier C, Linglart A, Rodrigue D, Teinturier C. [The role of gonadal peptides in clinical investigation]. Ann Biol Clin (Paris). 2009;67(3):283-92.

26. Achermann JC, Domenice S, BachegaTA, Nishi MY, Mendonca BB. Disorders of sex development: effect of molecular diagnostics. Nat Rev Endocrinol. 2015;11(8):478-88.

27. Hellwinkel OJ, Holterhus PM, Struve D, Marschke C, Homburg $\mathrm{N}$, Hiort $\mathrm{O}$. A unique exonic splicing mutation in the human androgen receptor gene indicates a physiologic relevance of regular androgen receptor transcript variants. J Clin Endocrinol Metab. 2001;86(6):2569-75.

28. Batista RL, Rodrigues ADS, Nishi MY, Gomes NL, Faria JAD Junior, Moraes DR, et al. A recurrent synonymous mutation in the human androgen receptor gene causing complete androgen insensitivity syndrome. J Steroid Biochem Mol Biol. 2017;174:14-16.

29. Akin JW, Behzadian A, Tho SP, McDonough PG. Evidence for a partial deletion in the androgen receptor gene in a phenotypic male with azoospermia. Am J Obstet Gynecol. 1991;165/6 Pt 1):1891-4.

30. Köhler B, Lumbroso S, Leger J, Audran F, Grau ES, Kurtz F, et al. Androgen insensitivity syndrome: somatic mosaicism of the androgen receptor in seven families and consequences for sex assignment and genetic counseling. J Clin Endocrinol Metab. 2005;90(1):106-11.

31. Batista RL, Rodrigues AS, Nishi MY, Feitosa ACR, Gomes NLRA, Junior JAF, et al. Heterozygous nonsense mutation in the androgen receptor gene associated with partial androgen insensitivity syndrome in an individual with 47,XXY karyotype. Sex Dev. 2017;11(2):78-81.

32. Ismail-Pratt IS, Bikoo M, Liao LM, Conway GS, Creighton SM. Normalization of the vagina by dilator treatment alone in Complete Androgen Insensitivity Syndrome and Mayer-Rokitansky-KusterHauser Syndrome. Hum Reprod. 2007;22(7):2020-4.

33. Costa EM, Mendonca BB, Inácio M, Arnhold IJ, Silva FA, Lodovici O. Management of ambiguous genitalia in pseudohermaphrodites: new perspectives on vaginal dilation. Fertil Steril. 1997;67(2): 229-32.
34. Hayashida SA, Soares JM Jr, Costa EM, da Fonseca AM, Maciel GA, Mendonça BB, et al. The clinical, structural, and biological features of neovaginas: a comparison of the Frank and the Mclndoe techniques. Eur J Obstet Gynecol Reprod Biol. 2015;186:12-6.

35. Sircili MH, e Silva FA, Costa EM, Brito VN, Arnhold IJ, Dénes FT, et al. Long-term surgical outcome of masculinizing genitoplasty in large cohort of patients with disorders of sex development. J Urol. 2010;184(3):1122-7.

36. Cools M, Looijenga LH, Wolffenbuttel KP,T'Sjoen G. Managing the risk of germ cell tumourigenesis in disorders of sex development patients. Endocr Dev. 2014;27:185-96.

37. Fischbeck KH. A role for androgen reduction treatment in Kennedy disease? Muscle Nerve. 2013;47(6):789.

38. Becker D, Wain LM, Chong YH, Gosai SJ, Henderson NK, Milburn $\mathrm{J}$, et al.Topical dihydrotestosterone to treat micropenis secondary to partial androgen insensitivity syndrome (PAIS) before, during, and after puberty - a case series. J Pediatr Endocrinol Metab. 2016;29(2):173-7.

39. Wünsch L, Holterhus PM, Wessel L, Hiort O. Patients with disorders of sex development (DSD) at risk of gonadal tumour development: management based on laparoscopic biopsy and molecular diagnosis. BJU Int. 2012;110(11 Pt C):E958-65.

40. Moch H, Cubilla AL, Humphrey PA, Reuter VE, Ulbright TM. The 2016 WHO Classification of Tumours of the Urinary System and Male Genital Organs-Part A: Renal, Penile, andTesticularTumours. Eur Urol. 2016;70(1):93-105.

41. van der Zwan YG, Cools M, Looijenga LH. Advances in molecular markers of germ cell cancer in patients with disorders of sex development. Endocr Dev. 2014;27:172-84.

42. Looijenga LH, Hersmus R, Oosterhuis JW, Cools M, Drop SL, Wolffenbuttel KP. Tumor risk in disorders of sex development (DSD). Best Pract Res Clin Endocrinol Metab. 2007;21(3):480-95.

43. Döhnert U, Wünsch L, Hiort O. Gonadectomy in Complete Androgen Insensitivity Syndrome: Why and When? Sex Dev. 2017;11(4):171-4.

44. Handa N, Nagasaki A, Tsunoda M, Ohgami H, Kawanami T, Sueishi $\mathrm{K}$, et al. Yolk sac tumor in a case of testicular feminization syndrome. J Pediatr Surg. 1995;30(9):1366-7.

45. Chaudhry S, Tadokoro-Cuccaro R, Hannema SE, Acerini CL, Hughes IA. Frequency of gonadal tumours in complete androgen insensitivity syndrome (CAIS): A retrospective case-series analysis. J Pediatr Urol. 2017;13(5):498.e1-498.e6.

46. Kaprova-Pleskacova J, Stoop $H$, Brüggenwirth $H$, Cools $M$, Wolffenbuttel KP, Drop SL. Complete androgen insensitivity syndrome: factors influencing gonadal histology including germ cell pathology. Mod Pathol. 2014;27(5):721-30.

47. Kathrins $M$, KolonTF. Malignancy in disorders of sex development. Transl Androl Urol. 2016;5(5):794-8.

48. Hiort O, Birnbaum W, Marshall L, Wünsch L, Werner R, Schröder $\mathrm{T}$, et al. Management of disorders of sex development. Nat Rev Endocrinol. 2014;10(9):520-9.

49. Nakhal RS, Hall-Craggs M, Freeman A, Kirkham A, Conway GS, Arora R, et al. Evaluation of retained testes in adolescent girls and women with complete androgen insensitivity syndrome. Radiology. 2013;268(1):153-60.

50. Cools M, Looijenga L. Update on the pathophysiology and risk factors for the development of malignant testicular germ cell tumors in complete androgen insensitivity syndrome. Sex Dev. 2017; 11(4):175-81.

51. Hiort $\mathrm{O}$, Holterhus PM. Androgen insensitivity and male infertility. Int J Androl. 2003;26(1):16-20.

52. Finlayson C, Fritsch MK, Johnson EK, Rosoklija I, Gosiengfiao $Y$, Yerkes $E$, et al. Presence of germ cells in disorders of sex 
development: implications for fertility potential and preservation. J Urol. 2017;197(3 Pt 2):937-43.

53. Chu J, Zhang R, Zhao Z, Zou W, Han Y, Qi Q, et al. Male fertility is compatible with an $\operatorname{Arg}(840)$ Cys substitution in the AR in a large Chinese family affected with divergent phenotypes of $A R$ insensitivity syndrome. J Clin Endocrinol Metab. 2002;87(1):347-51.

54. Tordjman KM, Yaron M, Berkovitz A, Botchan A, Sultan C, Lumbroso S. Fertility after high-dose testosterone and intracytoplasmic sperm injection in a patient with androgen insensitivity syndrome with a previously unreported androgen receptor mutation. Andrologia. 2014;46(6):703-6.

55. Cohen-Kettenis PT. Psychosocial and psychosexual aspects of disorders of sex development. Best Pract Res Clin Endocrinol Metab. 2010;24(2):325-34.

56. Mendonca BB. Gender assignment in patients with disorder of sex development. Curr Opin Endocrinol Diabetes Obes. 2014;21(6):511-4.
57. Bermúdez de la Vega JA, Fernández-Cancio M, Bernal S, Audí L. Complete androgen insensitivity syndrome associated with male gender identity or female precocious puberty in the same family. Sex Dev. 2015;9(2):75-9.

58. de Vries AL, Doreleijers TA, Cohen-Kettenis PT. Disorders of sex development and gender identity outcome in adolescence and adulthood: understanding gender identity development and its clinical implications. Pediatr Endocrinol Rev. 2007;4(4):343-51.

59. Callens N, Van Kuyk M, van Kuppenveld JH, Drop SLS, CohenKettenis PT, Dessens AB, et al. Recalled and current gender role behavior, gender identity and sexual orientation in adults with Disorders/Differences of Sex Development. Horm Behav. 2016;86:8-20.

60. Doehnert U, Bertelloni S, Werner R, Dati E, Hiort O. Characteristic features of reproductive hormone profiles in late adolescent and adult females with complete androgen insensitivity syndrome. Sex Dev. 2015;9(2):69-74. 